\title{
O DEPÓSITO POTASSÍFERO DE AUTAZES NO CONTEXTO ESTRATIGRÁFICO DA BACIA DO AMAZONAS
}

\author{
THE AUTAZES POTASH DEPOSIT IN THE STRATIGRAPHIC CONTEXT \\ OF THE AMAZON BASIN
}

\author{
Gustavo Lage Sousa KIEFER ${ }^{1,3}$, Alexandre ULHEIN ${ }^{2}$, José Jacob FANTON ${ }^{3}$ \\ ${ }^{1}$ Programa de Pós-graduação em Geociências, Instituto de Geociências, Universidade Federal de Minas Gerais, Av. Antônio Carlos, \\ 6627, Campus Pampulha, Belo Horizonte, MG, Brasil. email:gustavokiefer@yahoo.com.br \\ ${ }^{2}$ Universidade Federal de Minas Gerais, Instituto de Geociências, Centro de Pesquisa Manoel Teixeira da Costa - CPMTC, Av. \\ Antônio Carlos, 6627, Campus Pampulha, Belo Horizonte, MG, Brasil.Email: auhlein@gmail.com \\ ${ }^{3}$ Potássio do Brasil Ltda., Rua Antônio de Albuquerque, 156, 150 andar, Funcionários, Belo Horizonte, MG, Brasil. Emails: \\ gkiefer@potassiodobrasil.com.br; fanton@potassiodobrasil.com.br
}

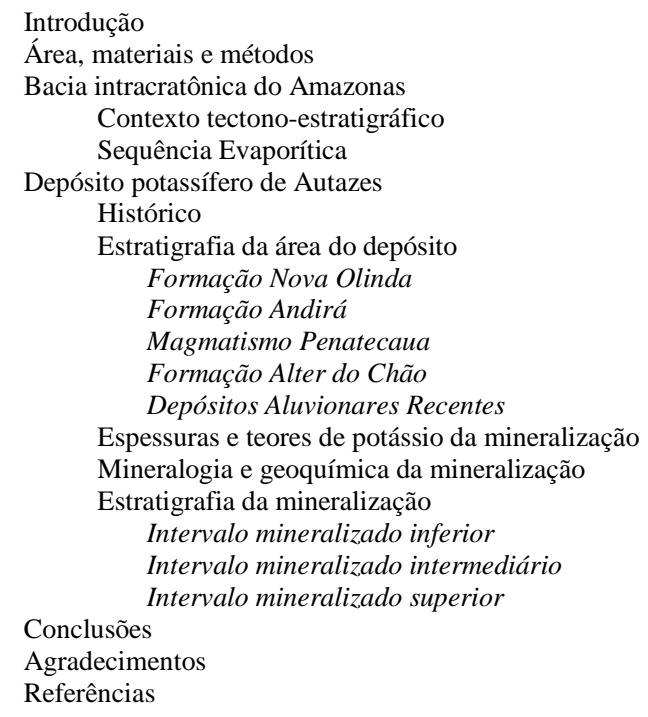

RESUMO - O Depósito Potassífero de Autazes, com reservas totais superiores a 767 Mt e teor médio de 30,71\% de cloreto de potássio $(\mathrm{KCl})$, corresponde a um horizonte mineralizado subhorizontal, posicionado nos estratos superiores da Formação Nova Olinda, da Sequência Pensilvaniana-Permiana da Bacia do Amazonas. Este trabalho apresenta as características mineralógicasgeoquímicas, estratigráficas e petrográficas da mineralização, a partir dos dados oriundos do programa de pesquisa mineral para sais de potássio empreendido pela Potássio do Brasil Ltda., entre os anos de 2008 e 2014, na região de Autazes, Amazonas, Brasil. Esses dados indicam que a mineralização abrange uma área de $155 \mathrm{~km}^{2}$, com espessura média de 2,07 m e situa-se entre as profundidades de $685 \mathrm{~m}$ e $865 \mathrm{~m}$. O horizonte mineralizado foi subdividido, da base para o topo, em: 1) Intervalo Mineralizado Inferior, com predomínio de silvinitas brancas, finas e laminadas; 2) Intervalo Mineralizado Intermediário, que apresenta principalmente silvinita castanha e sulfatos disseminados; 3) Intervalo Mineralizado Superior, constituído por silvinitas avermelhadas, com granulação grosseira. As distribuições dos teores de $\mathrm{KCl}$ e espessuras da mineralização estão relacionados às características distintivas dessas unidades ao longo do depósito.

Palavras-chave: Evaporitos, Silvinita, Formação Nova Olinda, Pensilvaniano-Permiano, Bacia do Amazonas.

ABSTRACT - The Autazes Potash Deposit, with more than $767 \mathrm{Mt}$ and average grade of $30.71 \%$ of potassium chloride (KCl), corresponds to a sub-horizontal mineralized horizon located in the upper strata of the Nova Olinda Formation, from PensilvanianaPermian Sequence of Amazon Basin. This study reports the mineralogical-geochemical, stratigraphic and petrographic features of the potash mineralization, based on the database obtained by Potássio do Brasil Ltd. during a mineral exploration campaign for potash salts undertaken from the years 2008 to 2014, in Autazes region, Amazonas State, Brazil. These data indicate that mineralization covers an area of $155 \mathrm{~km}^{2}$, with an average thickness of $2.07 \mathrm{~m}$ and lies at depth from $685 \mathrm{~m}$ to $865 \mathrm{~m}$. The mineralized horizon was subdivided from bottom to top as: 1) Lower Mineralized Interval, with predominance of white, fine and laminated sylvinites; 2) Intermediate Mineralized Interval, which mainly presents brown sylvinite and disseminated sulphates; 3) Upper Mineralized Interval, consisting of reddish coarse sylvinites. The $\mathrm{KCl}$ content and thickness distributions of the mineralization are related to the distinctive features of these sections along the deposit.

Keywords: Evaporite, Sylvinite, Nova Olinda Formation, Pensilvanian-Permian, Amazon Basin.

\section{INTRODUÇÃO}

Os depósitos evaporíticos de potássio no região, a produção de potássio está restrita à Brasil são encontrados, em grande parte, no Mina de Taquari/Vassouras, em Sergipe, que Aptiano da Bacia Sergipe-Alagoas. Nesta está sob controle da mineradora Mosaic 
Fertilizantes. Destacam-se também as reservas Permo-Carboníferas das bacias intracratônicas do Solimões e Amazonas (Kulaif \& Góes, 2016) que, no futuro, podem assumir grande importância no fornecimento de potássio para a indústria de fertilizantes do Brasil. A maior parte dos fertilizantes potássicos utilizados na agricultura mundial é obtida a partir do cloreto de potássio (KCl), devido à sua alta concentração e baixo custo de produção (Dias \& Fernandes, 2006). Assim, os depósitos da Bacia do Amazonas constituem-se na melhor perspectiva de elevar significativamente a produção de cloreto de potássio no Brasil (Marini, 2006).

Entre os anos de 2008 e 2009, a companhia Potássio do Brasil iniciou um robusto projeto de pesquisa mineral para sais de potássio na Bacia do Amazonas, a partir da aquisição e interpretação de dados públicos regionais do Banco de Dados de Exploração e Produção
(BDEP) da Agência Nacional do Petróleo, Gás Natural e Biocombustíveis (ANP). Dentre as áreas selecionadas pela companhia, a região de Autazes, na Bacia do Amazonas, foi a primeira a receber o programa de sondagem, executado entre os anos de 2010 a 2014, que culminou na definição do Depósito de Autazes, com reservas totais superiores a $767 \mathrm{Mt}$ e teor médio de 30,71\% de KCl (Potássio do Brasil, 2014).

Este trabalho objetiva apresentar dados de estratigrafia, geoquímica e mapas de espessura e teores de potássio, mineralogia, petrografia e descrições dos intervalos da mineralização de potássio, que corresponde ao denominado Depósito de Autazes, situado na Bacia do Amazonas (Figura 1). Os dados geológicos aqui apresentados são inéditos e representam um caso de grande sucesso de pesquisa mineral empreendido na Bacia do Amazonas (Potássio do Brasil, 2014).

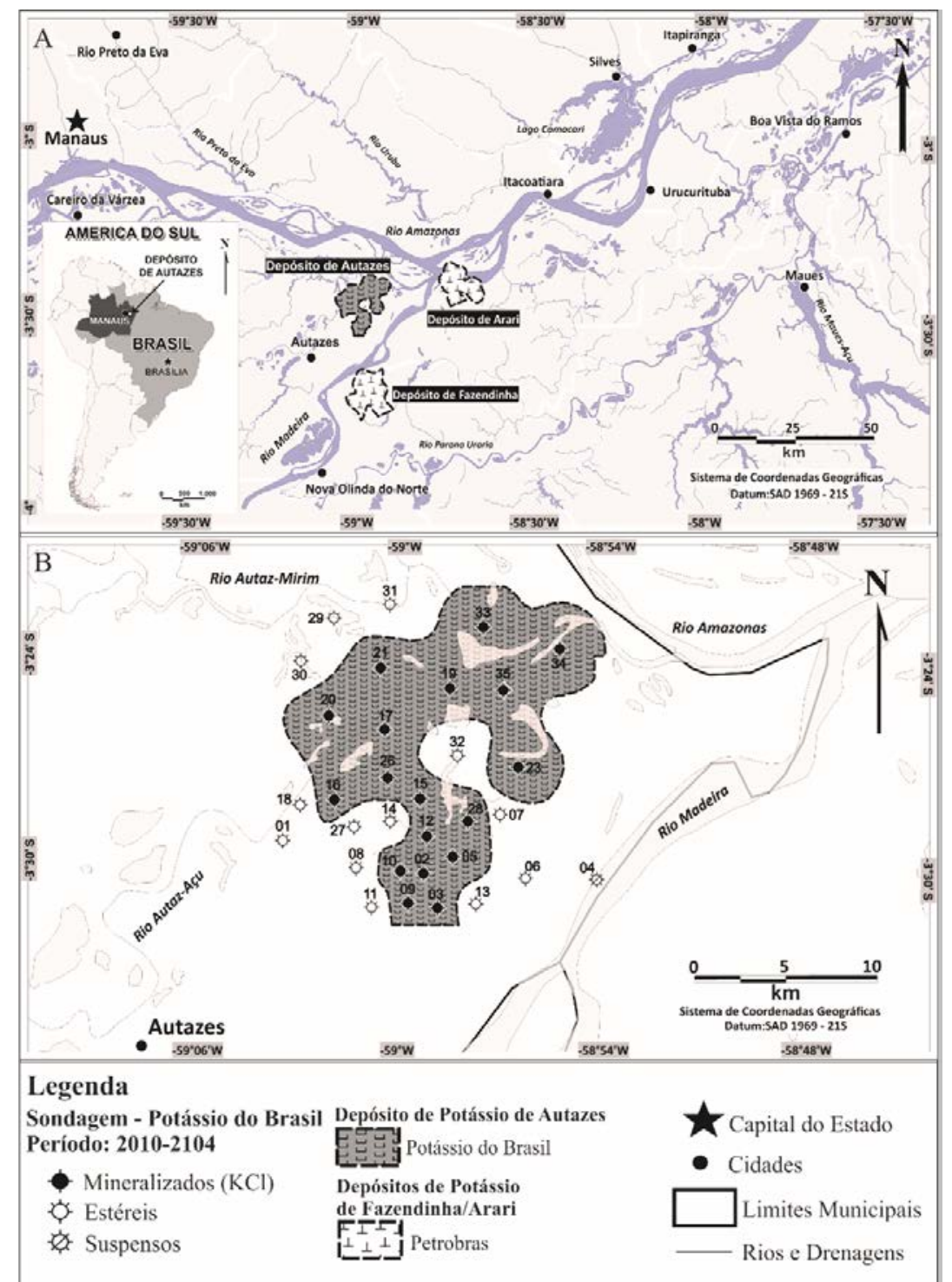

Figura 1 - Mapas de localização: A) Depósitos potassíferos na Bacia do Amazonas; B) Limites estimados para o Depósito Potassífero de Autazes (modificadp de Potássio do Brasil, 2014). 


\section{ÁREA, MATERIAL E MÉTODOS}

O Depósito Potássifero de Autazes, objetivo principal deste trabalho, corresponde a uma área de $155 \mathrm{~km}^{2}$, com reservas totais superiores a 767 Mt e teor médio de 30,71\% de $\mathrm{KCl}$. O depósito está localizado entre as longitudes $-59^{\circ} \quad 03^{\prime}$ $25,308^{\prime \prime} \mathrm{W}$ e $-58^{\circ} 53^{\prime} 49,088^{\prime \prime} \mathrm{W}$ e latitudes $-03^{\circ}$ $31^{\prime} 44,652 " S$ e $-03^{\circ} 21^{\prime} 44,920 " S$, distante cerca de $22 \mathrm{~km}$ a nordeste do município de Autazes e a $120 \mathrm{~km}$ a sudeste da capital do Estado, Manaus (Fig. 1) A área do depósito está inserida na porção oeste da Bacia do Amazonas, próxima à confluência dos rios Autaz Mirim, Autaz- Açu, Madeira e Amazonas (Potássio do Brasil, 2014).

O trabalho apresentado é resultado da avaliação e interpretação de dados de sondagem, oriundos da campanha de pesquisa mineral empreendida pela Potássio do Brasil na região de Autazes. Esses dados correspondem a um total aproximado de $27.000 \mathrm{~m}$ de amostras de rochas do espectro sedimentar Fanerozoico da Bacia do Amazonas, obtidas a partir de 33 furos de sondagem executados pela empresa nessa região, até o ano de 2014.

A sondagem rotativa diamantada pelo sistema wireline foi a metodologia de pesquisa mineral utilizada na definição do Depósito de Autazes. Os furos de sonda foram executados em três etapas subsequentes: 1) Perfuração com brocas tricônicas com diâmetros entre 21,6 cm a $30,5 \mathrm{~cm}$ e amostragem de fragmentos sedimentares de calha até aproximadamente 400 m de profundidade; 2) Perfuração com coroas diamantadas (padrões HQ e PQ) e recuperação de testemunhos de rochas sedimentares clásticas, até aproximadamente $770 \mathrm{~m}$ de profundidade; 3) Perfuração com coroas diamantadas (padrões NQ e HQ) e recuperação de testemunhos de rochas salinas, até aproximadamente 850 metros de profundidade.

Para a determinação analítica dos teores de potássio presentes, foram executadas 1557 análises químicas, num total de $280 \mathrm{~m}$ de amostras de rochas salinas selecionadas em todos os furos de sondagem realizados em Autazes. As análises químicas foram realizadas nos laboratórios do Saskatchewan Research Council (SRC) em Saskatchewan, no Canadá. As amostras foram analisadas por ICP-OES (espectrometria de emissão ótica com plasma indutivamente acoplado) (Potássio do Brasil, 2014).

Para a determinação das frações mineralógicas, foram executadas análises por meio de difratometria de Raios X (DRX), no Centro de Microanálises Avançadas da SRC. Ao todo, foram realizadas 1248 análises mineralógicas, correspondentes a um total de 265,04 m de amostras salinas (Potássio do Brasil, 2014).

Os resultados das análises químicas foram compostos em intervalos variados para cada furo de sondagem. Nesse processo, foram selecionados intervalos com teores iguais e superiores a $10 \%$ de $\mathrm{KCl}$ para a definição da mineralização. Esse critério foi definido a partir do tratamento estatístico dos resultados químicos que indicou um padrão de continuidade do horizonte mineralizado com esse teor de corte. Dessa forma, foram definidos 18 furos com intersecções mineralizadas em $\mathrm{KCl}$ que permitiram a avaliação das reservas geológicas em Autazes (Potássio do Brasil, 2014).

A estimativa das reservas foi executada com auxílio do software GeoviaGems (versão 6.6). Este processo considerou a interpolação de diversas seções verticais a partir dos furos de sondagem obtendo-se um modelo 3D do corpo mineralizado e o volume e o teor das reservas contidas, conforme o método dos polígonos (Yamamoto, 2001) (Potássio do Brasil, 2014).

\section{BACIA INTRACRATÔNICA DO AMAZONAS}

\section{Contexto tectono-estratigráfico}

A Bacia do Amazonas situa-se na porção setentrional do Brasil e distribui-se por uma área de aproximadamente $500.000 \mathrm{~km}^{2}$ entre os estados do Amapá, Amazonas e Pará (Almeida \& Hasui, 1984; Santos, 2003). A bacia está localizada no interior do Cráton Amazônico, cuja porção norte denomina-se: Escudo das Guianas e a porção sul, Cráton Brasil Central (ou Guaporé), ambos constituídos por rochas granito-gnáissicas arqueanas e várias coberturas paleo-meso-proterozoicas (Santos, 2003; Tassinari \& Macambira, 2004; Uhlein et al., 2015) (Figura 2).

Segundo Neves et al. $(1989,1990)$ e Cunha (1994, 2000), o surgimento da Bacia do Amazonas estaria associado aos estágios colisionais finais do Ciclo Brasiliano (Neoproterozóico). A colisão dos crátons do São Francisco e Amazônico no Neoproterozoico teria 


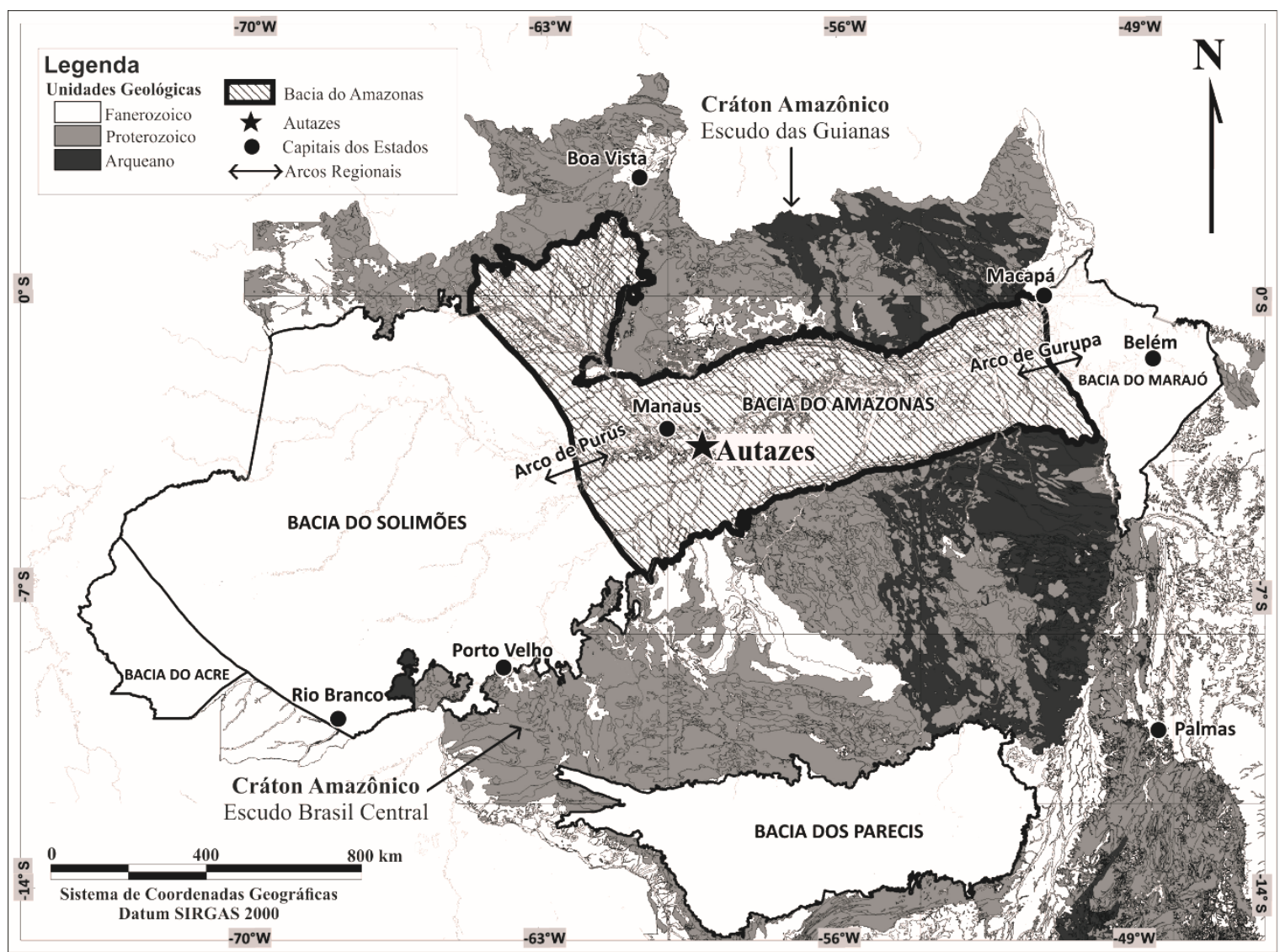

Figura 2 - Mapa de localização da Bacia do Amazonas no contexto do Cráton Amazônico (adaptado de CPRM, 2004) e localização do Depósito de Autazes.

originado esforços distensivos de relaxamento, que possibilitaram a geração do rifte precursor da Bacia do Amazonas. A compartimentação do embasamento e os "trends" estruturais mais antigos teriam controlado a sedimentação ordoviciana ( 460 Ma) da base da Bacia do Amazonas (Cunha, 2000; Cunha et al, 2007).

O preenchimento sedimentar da Bacia do Amazonas é representado principalmente por rochas paleozoicas, com espessuras que atingem mais de $5.000 \mathrm{~m}$. A estratigrafia da bacia corresponde a duas megassequências de primeira ordem: uma paleozoica, representada por rochas sedimentares de variados ambientes deposicionais, associadas à volumosa ocorrência de intrusões de diques e soleiras de diabásio de idades mesozoicas; e outra de idades mesocenozóicas (Caputo et al, 1972; Campos \& Teixeira, 1988; Cunha et al, 1994; Cunha, 2000; Cunha et al., 2007).

A Megassequência Paleozoica é ainda subdividida em quatro sequências de segunda ordem, denominadas: Sequência OrdovícioDevoniana, Sequência Devono-Tournaisiana, Sequência Neoviseana e Sequência Pensilvaniano-Permiana. Em todas essas divisões são registradas variações deposicionais associadas a discordâncias regionais, decorrentes dos eventos tectônicos ocorridos nos limites da Placa Gondwânica no Paleozoico (Cunha et al., 2007).

A Sequência Ordovício-Devoniana representa o estágio inicial de deposição da bacia intracratônica do Amazonas. Possui espectro sedimentar de origem glacial a marinha, com influência de ciclos transgressivos-regressivos. A Sequência Devono-Tournaisiana corresponde ao estabelecimento de um novo ciclo transgressivoregressivo, associado a sedimen-tação glacial, iniciado após a discordância basal. A Sequência Neoviseana é representada pelos sedimentos da Formação Faro, constituída por arenitos e pelitos flúvio-deltaicos a litorâneos. A Sequência Pensilvaniano-Permiana, hospedeira da mineralização de potássio, representa o estabelecimento de um novo ciclo transgressivoregressivo na Bacia do Amazonas, a partir do Neocarbonífero, após um hiato deposicional de cerca de 15 Ma desde a deposição da Sequência Neoviseana. Essa sequência é representada pelas formações Monte Alegre, Itaituba, Nova Olinda e Andirá, pertencentes ao Grupo Tapajós. A sedimentação da sequência é iniciada por arenitos eólicos e de wadis, intercalados com siltitos e folhelhos de 
interdunas e lagos da Formação Monte Alegre (Costa, 1984; Cunha, 2000; Cunha et al., 2007). No avanço do evento transgressivo, foram depositados em seguida os sedimentos de fácies lagunar e marinho rasa/inframaré, compostos por folhelhos, carbonatos e anidritas $\left(\mathrm{CaSO}_{4}\right)$ da Formação Itaituba (Lemos, 1990; Cunha et al., 2007). Estratigraficamente acima, estão os sedimentos da Formação Nova Olinda que correspondem a calcários, anidritas e halitas $(\mathrm{NaCl})$ de ambiente de planície de maré (inframaré) e planícies de sabkha, onde ocorre o Depósito Potassífero de Autazes, objetivo principal deste trabalho. No topo da sequência, ocorrem os sedimentos da Formação Andirá, de caráter predominantemente continental, compostos por siltitos e arenitos avermelhados (redbeds) e raras anidritas, correspondentes às fácies fluviais e lacustrinas. Essa associação sedimentar representa a generalização do assoreamento continental na bacia no Permiano (Cunha et al., 2007).

Diques e soleiras de diabásio, ocorrem intrudidos na Megassequência Paleozoica, associados a processos distensivos. As datações $\mathrm{Ar}-\mathrm{Ar}$ dessas rochas ígneas indicam idades entre 210 Ma e $191 \mathrm{Ma}$, com idade mais provável de 200 Ma para os eventos magmáticos (Aires, 1983; Thomaz Filho et al. 1974; Zalán, 2004; Cunha et al., 2007).

A Megassequência Meso-Cenozoica representa o topo da Bacia do Amazonas, e é constituída pelo Grupo Javari, subdividido nas Formações Alter do Chão e Solimões. Essas formações recobrem a superfície de discordância relacionada à Orogenia Gonduanide (discordância pré-cretácea), que marca o topo das sequências paleozoicas (Caputo et al, 1972; Cunha et al., 1994; 2007). A Formação Alter do Chão é composta por arenitos grossos, atribuídos a um sistema fluvial de alta energia desenvolvido durante o Cretáceo, além de arenitos e conglomerados de fácies de planície e leques aluviais. Acima, em discordância, ocorrem os sedimentos da Formação Solimões, que correspondem a um prisma argiloso com distribuição limitada a porção ocidental da bacia, até o limite do Arco de Purus (Cunha et al., 2007).

\section{Sequência evaporítica da Bacia do Amazonas}

Szatmari et al. (1975) propuseram a denominação de Sequência Evaporítica para o conjunto de sedimentos químico-evaporíticos e terrígenos das formações Itaituba, Nova Olinda e parte da Formação Andirá do Grupo Tapajós, na Bacia do Amazonas. Esses autores efetuaram excelente trabalho de estratigrafia cíclica, descrevendo diversos ciclos sedimentares associados a variações maiores ou menores na salinidade paleoambiental, para as Formações Itaituba e Nova Olinda. Definiram, desta forma, um Ciclo Principal que subdivide-se em onze ciclos secundários, correlacionáveis ao longo da bacia e limitados no topo e na base por sedimentos terrígenos (folhelhos e mais raramente siltitos e arenitos). Dentre os ciclos secundários assim definidos, o Ciclo VII é o que representa o alcance máximo de saturação da salinidade paleoambiental, representando o período de mais efetivo isolamento da bacia. No Ciclo VII as salmouras atingiram altas concentrações, que resultaram na deposição de halitas bandadas finamente cristalizadas e sais solúveis na forma de cloretos e sulfatos de potássio e magnésio (Szatmari et al. 1975; Sad et al. 1982, 1997).

No Quadro I observa-se a estratigrafia cíclica conforme trabalho original de Szatmari et al (1975), estabelecida para as Formações Itautuba, Nova Olinda e Andira. Nesses ciclos, as variações de salinidade das salmouras residuais bacinais são inferidas pelas fácies evaporíticas. Assim, os carbonatos e sulfatos representam as fases de baixa a média salinidades originais, enquanto os cloretos, os estágios de alta concentração salina paleoambiental (Warren, 2006).

A mesma classificação cicloestratigráfica foi proposta por Sad et al. (1982, 1997), que atribuiram à associação de fácies da Sequência Evaporítica a recorrência cíclica de fases de alta e baixa salinidade, limitadas por folhelhos pretos ou por sais menos solúveis (calcários ou anidritas), que permite a sua subdivisão em onze ciclos. Cada ciclo seria então composto de uma sequência de sedimentos clásticos na base (folhelhos e/ou arenitos) e outra, superior, de sedimentos químicos, iniciada com carbonatos e anidrita, e finalizada com halita no topo (Szatmari et al. 1975; Costa \& Wanderley Filho, 2009).

Assim, embora nas últimas décadas a análise cicloestratigráfica dos evaporitos da Bacia do Amazonas tenha imperado ao longo das publicações científicas, destaca-se aqui, a possibilidade de abordagens mais amplas à luz dos conceitos da moderna Estratigrafia de Sequências. 


\section{DEPÓSITO POTASSÍFERO DE AUTAZES}

\section{Histórico}

A presença de evaporitos na Bacia do Amazonas foi descoberta durante a execução do furo de sondagem (1-NO-1-AM) pela Petrobras, entre os anos de 1953 e 1957, em Nova Olinda do Norte, no Amazonas. Posteriormente, em 1974 foi possível identificar a presença de camada de silvinita nessa região com a execução dos poços 1-FZ-1-AM e 1-FZ-2-AM (Costa \& Wanderley Filho, 2009; Kulaif \& Góes, 2016).

Ao final da década de 1970, foi iniciado um amplo programa de avaliação do potencial potassífero da Bacia do Amazonas, com a criação de um consórcio de pesquisa entre a Petrobras Mineração S.A. (Petromisa) e a CPRM. A fase seguinte correspondeu à campanha de sondagem exploratória na área denominada Fazendinha, pertencente ao município de Nova Olinda do Norte, às margens do rio Madeira, a $130 \mathrm{~km}$ de Manaus. Os furos executados nessa região, permitiram a identificação de camadas porta-doras de sais de potássio com espessuras e teores suficientes para definição do Depósito de Fazen-dinha, com reservas medidas in situ superiores

Quadro 1. Associação faciológica do Ciclo Principal da Sequência Evaporítica da Bacia do Amazonas (modificado de Szatmari et al., 1975; Sad et al. 1982, 1997).

\begin{tabular}{|c|c|c|c|}
\hline \multicolumn{4}{|c|}{ Bacia do Amazonas } \\
\hline Salinidade & Litologia & $\begin{array}{c}\text { Espessura } \\
(\mathrm{m})\end{array}$ & $\begin{array}{c}\text { Ciclos } \\
\text { Secundários } \\
\end{array}$ \\
\hline Mínima & Halitas grosseiras & \multirow{3}{*}{350} & \multirow{3}{*}{ IX } \\
\hline \multirow{4}{*}{ 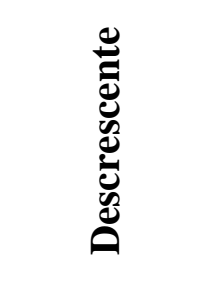 } & Anidritas & & \\
\hline & Arenitos & & \\
\hline & Halitas grosseiras recristalizadas & \multirow{2}{*}{200} & \multirow{2}{*}{ VIII } \\
\hline & Halitas cristaloblásticas & & \\
\hline \multirow{2}{*}{ Máxima } & Halitas finas de alta concentração & \multirow{2}{*}{$150 / 200$} & \multirow{2}{*}{ VII } \\
\hline & Silvinitas ( $\mathrm{NaCl}+\mathrm{KCl})$ & & \\
\hline \multirow{8}{*}{ 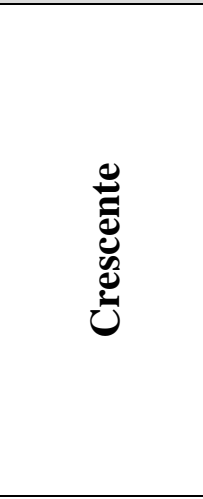 } & Halita grosseira & 175 & VI \\
\hline & Anidrita nodular & \multirow[b]{2}{*}{255} & \multirow[b]{2}{*}{$\mathrm{V}$} \\
\hline & $\begin{array}{l}\text { Anidrita nodular com intercalação arenitos e } \\
\text { siltitos }\end{array}$ & & \\
\hline & Calcário e anidrita & 175 & IV \\
\hline & Calcário e anidrita com intercalação de arenito & 300 & III \\
\hline & Calcário e anidrita + arenito & 90 & II-A \\
\hline & Ausente & - & II \\
\hline & Ausente & - & I-A \\
\hline Mínima & Ausente & - & $\mathrm{I}$ \\
\hline
\end{tabular}

a 520 Mt de minério com 28,8\% de $\mathrm{KCl}$. Com a descoberta de Fazendinha, uma segunda área denominada Arari, também na região de Nova Olinda do Norte, foi alvo de campanha exploratória pelo consórcio, entre os anos de 1982 e 1987. Nessa área, localizada aproximadamente a $150 \mathrm{~km}$ de Manaus, próxima à confluência dos rios Madeira e Amazonas, os furos executados também intersectaram mineralização potassífera e permitiram a identificação do Depósito de Arari, com reservas da ordem de $659 \mathrm{Mt}$ com $17,7 \%$ de $\mathrm{KCl}$ (Sad et al. 1982, 1997; Dardenne \& Schobbenhaus, 2001; Agapito, 2008).

Entre os anos de 2008 a 2014, a companhia Potássio do Brasil desenvolveu um projeto de pesquisa mineral para sais de potássio na Bacia do Amazonas, que culminou na identificação do Depósito de Autazes. 


\section{Estratigrafia da área do depósito}

A sondagem empreendida pela Potássio do Brasil interceptou 5 unidades litoestratigráficas na área do Depósito de Autazes, dispostas em sequência, da base para o topo: 1) Formação Nova Olinda (Carbonífero); e 2) Formação Andirá (Permiano), ambas pertencentes ao Grupo Tapajós; 3) soleiras de diabásio relacionadas ao magmatismo Juro-Triássico Penatecaua; 4) Formação Alter do Chão (Cretáceo), pertencente ao Grupo Javari; e (5) depósitos aluvionares recentes (Holoceno). As unidades paleozoicas apresentam grande continuidade lateral ao longo do depósito e estão dispostas na direção NE-SW, com suave mergulho para sudeste. $\mathrm{O}$ contato entre as
Formações Nova Olinda e Andirá é brusco e, entre a Formação Andirá e Alter do Chão, é marcado por discordância angular erosiva. Os depósitos aluvionares recentes também estão sobrepostos, de forma discordante, à Formação Alter do Chão.

A coluna estratigráfica do Depósito de Autazes, deduzida pelas sondagens realizadas é mostrada na figura 3 .

Formação Nova Olinda

A Formação Nova Olinda foi intersectada em todos os furos executados em Autazes, com espessuras mínima, máxima e média identificadas, respectivamente de 208,00 m, 334,45 m e $275,98 \mathrm{~m}$, sendo ligeiramente menos espessa em direção a NW. Essa formação está distribuída

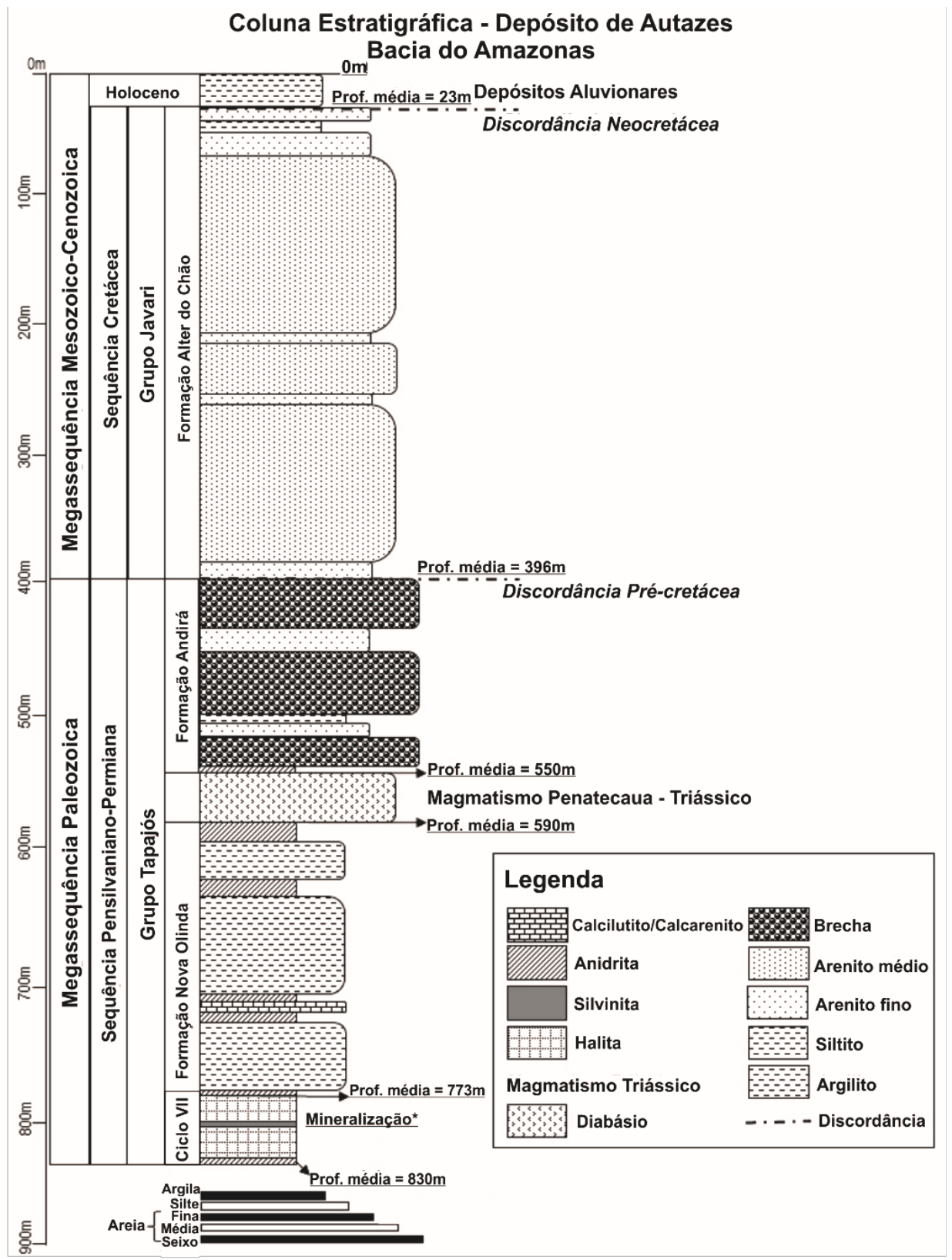

Figura 3 - Coluna estratigráfica da Bacia do Amazonas na área do Depósito de Autazes (modificado de Potássio do Brasil, 2014). *A estratigrafia da mineralização é apresentada na Figura 5. 
homogeneamente por todo o depósito entre as profundidades de $428 \mathrm{~m}$ no extremo noroeste e $960 \mathrm{~m}$ no extremo sudeste. Os estratos da unidade possuem direção NE-SW e mergulho suave em direção a sudeste. O contato basal com a Formação Itaituba não foi intersectado pelas sondagens realizadas em Autazes, enquanto o contato de topo, com a Formação Andirá, é definido pela última sequência de anidritas da formação, que marca o fim do caráter químico e a efetiva continentalização da bacia. $\mathrm{Na}$ área do Depósito de Autazes, a Formação Nova Olinda foi individualizada em: 1) Sequência Basal, ou evaporítica, correspondente ao topo do Ciclo Trangressivo-Regressivo VII, constituído por halitas, anidritas e pela mineralização potássifera na forma de cloretos e sulfatos de potássio e magnésio; e 2) Sequência Superior, predominantemente clástica, constituída por siltitos carbonáticos maciços de coloração marrom a cinza, com variações gradacionais de calcarenitos e arenitos muito finos, e cristais subédricos milimétricos a centimétricos de anidrita, dispostos de maneira dispersa, em aglomerados ou níveis centimétricos. Também são comuns intercalações de anidritas nodulares e laminadas e brechas sedimentares, com arcabouço constituído por grânulos e seixos de anidrita, siltito e arenito. O contato da sequência superior, com a basal é definido por anidritas laminadas ou nodulares sobrepostas a um horizonte de halita de granulação grossa com alto conteúdo de terrígenos (Potássio do Brasil, 2014).

\section{Formação Andirá}

A Formação Andirá foi identificada em todos os furos executados pela Potássio do Brasil em Autazes, com espessura média de 152,50 m. A exemplo da Formação Nova Olinda, os sedimentos da Formação Andirá dispõem-se na direção NE-SW, com mergulho suave para sudeste e tornam-se menos espessos em direção a noroeste. O contato de topo da unidade é discordante e erosivo com os sedimentos arenosos da Formação Alter do Chão.

Na Formação Andirá predominam calcilutitos de coloração marrom a cinza, com intercalações métricas a decamétricas de calcarenito marrom amarelado. Também são comuns espessos pacotes de brecha sedimentar suportada por matriz carbonática, arenosa ou silto-argilosa de coloração marrom, com arcabouço constituído por clastos de siltito, arenito e anidrita. $\mathrm{Na}$ base, ocorrem intercalações centimétricas a métricas de anidrita nodular de coloração cinza claro e, no topo, predominam arenito lítico de matriz carbonática e fragmentos angulosos de arenito e siltito (Potássio do Brasil, 2014).

\section{Magmatismo Penatecaua}

Na região do Depósito de Autazes há a ocorrência de uma soleira principal intrudida no topo da Formação Nova Olinda, com espessura média de 42,82 m. Essas rochas ígneas relacionam-se ao magmatismo Penatecaua e são constituídas por diabásio cinza escuro a preto esverdeado, com textura fanerítica fina à média, com cristais prismáticos de plagioclásio, piroxênio e magnetita, além de anfibólio e clorita secundários.

\section{Formação Alter do Chão}

A Formação Alter do Chão foi intersectada em todos os furos executados pela Potássio do Brasil na região, constituindo a formação mais expressiva na área de estudo, com espessura média de $373,31 \mathrm{~m}$. Os contatos de base e de topo desta unidade com os sedimentos da Formação Andirá, e com os Depósitos Aluvionares recentes, representam, respectivamente, as discordâncias regionais Pré-Cretácea e Neocretácea da Bacia do Amazonas (Figura 3). Na área do depósito a formação é constituída principalmente por espesso pacote de quartzo arenitos predominantemente de coloração bege a avermelhada, com ampla maturidade textural e mineralógica, frequentemente intercalados com sedimentos silto-argilosos.

\section{Depósitos Aluvionares Recentes}

Depósitos aluvionares recentes afloram em amplas porções da área do Depósito de Autazes, tendo sido identificados em quase todas as sondagens executadas pela Potásio do Brasil na região. Possuem espessura média de 22,95 m, constituídos por sedimentos argilosos e arenosos, parcialmente lateritizados.

\section{ESPESSURAS E TEORES DE POTÁSSIO DA MINERALIZAÇÃO}

O depósito potassífero de Autazes compreende um horizonte de minerais evaporíticos inseridos na Formação Nova Olinda. Por meio do programa de sondagens da Potássio do Brasil foi possível delimitar o corpo mineralizado, bem como avaliar a distribuição das espessuras e teores, apresentados de forma sistemática na Tabela 1.

As interseções definidas indicam que a 
Tabela 1. Espessuras e teores de $\mathrm{KCl}$ dos intervalos mineralizados intersectados no Depósito de Autazes (modificado de Potássio do Brasil, 2014).

\begin{tabular}{cccccccc}
\hline Furo & $\begin{array}{c}\text { Profundidade } \\
(\mathbf{m})\end{array}$ & $\begin{array}{c}\text { Espessura } \\
(\mathbf{m})\end{array}$ & $\mathbf{K C l \%}$ & Furo & $\begin{array}{c}\text { Profundidade } \\
(\mathbf{m})\end{array}$ & $\begin{array}{c}\text { Espessura } \\
(\mathbf{m})\end{array}$ & KCI\% \\
\hline $\mathbf{0 2}$ & 841,78 & 1,46 & 39,16 & $\mathbf{1 9}$ & 738,72 & 1,90 & 25,41 \\
$\mathbf{0 3}$ & 863,32 & 1,37 & 25,76 & $\mathbf{2 0}$ & 685,45 & 2,14 & 31,87 \\
$\mathbf{0 5}$ & 849,23 & 0,69 & 4,40 & $\mathbf{2 1}$ & 695,00 & 2,03 & 15,26 \\
$\mathbf{0 9}$ & 843,08 & 1,82 & 38,32 & $\mathbf{2 3}$ & 843,44 & 2,51 & 43,39 \\
$\mathbf{1 0}$ & 808,65 & 1,05 & 8,58 & $\mathbf{2 6}$ & 753,04 & 4,03 & 32,53 \\
$\mathbf{1 2}$ & 823,59 & 2,07 & 38,62 & $\mathbf{2 8}$ & 847,89 & 2,08 & 33,85 \\
$\mathbf{1 5}$ & 771,21 & 1,86 & 32,76 & $\mathbf{3 3}$ & 732,92 & 2,72 & 33,04 \\
$\mathbf{1 6}$ & 723,44 & 2,03 & 28,45 & $\mathbf{3 4}$ & 790,24 & 1,31 & 9,70 \\
$\mathbf{1 7}$ & 719,64 & 2,81 & 35,56 & $\mathbf{3 5}$ & 768,27 & 3,40 & 34,46 \\
\hline
\end{tabular}

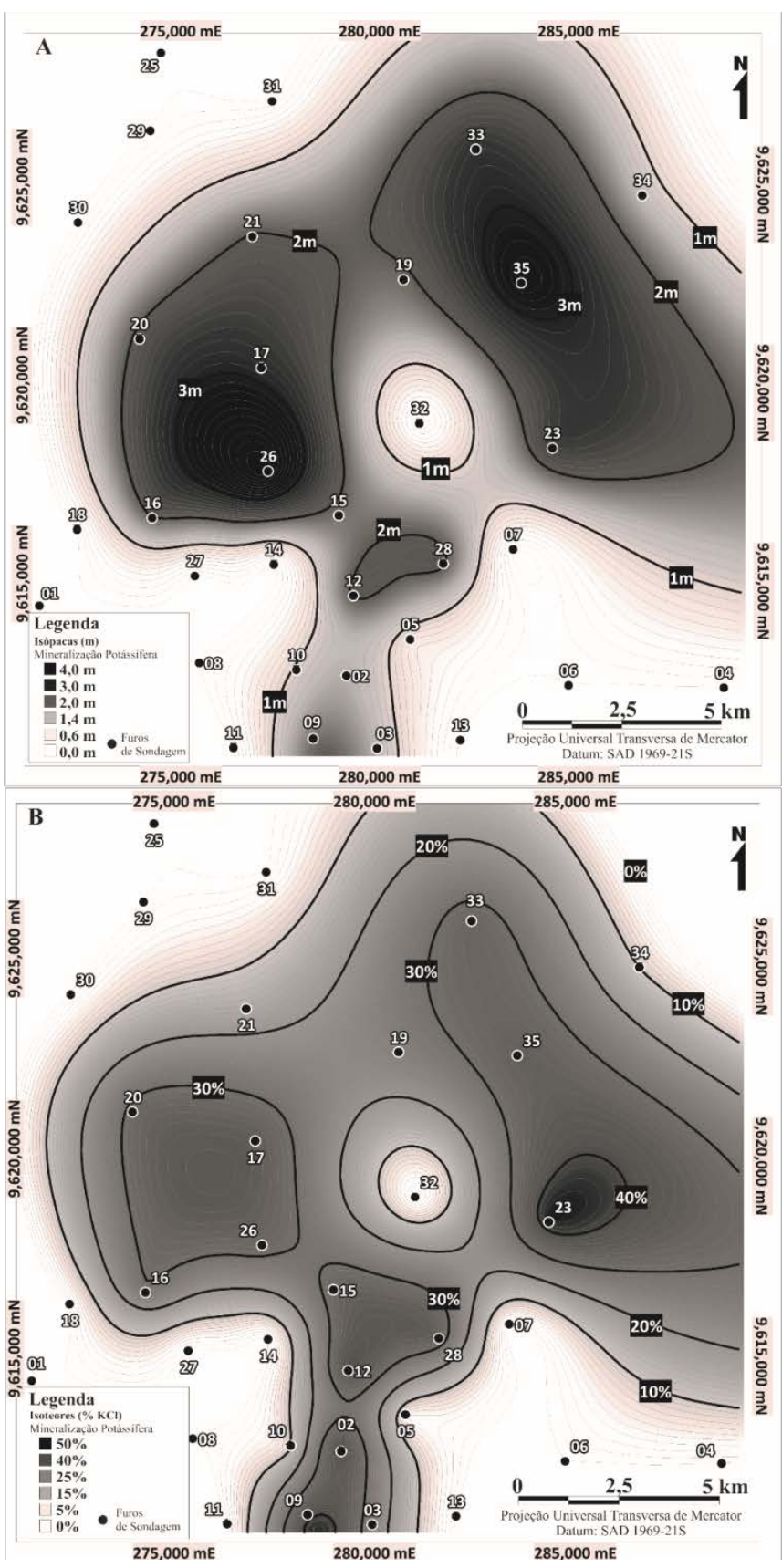

Figura 4 - Mapas com a distribuição da mineralização potassífera do Depósito de Autazes. Os furos de sondagem são mostrados para referência. A) Isópacas da mineralização; B) Isoteores de KCl da mineralização (modificado de Potássio do Brasil, 2014). 
mineralização em Autazes possui uma espessura mínima de 0,69 m e máxima de 4,03 m, respectivamente, nos furos 05 , no sul do depósito e 26, na porção noroeste, sendo a média geral de $2,07 \mathrm{~m}$. O teor de $\mathrm{KCl}$, por sua vez, oscila entre $4,40 \%$ no furo 05 , até $43,39 \%$ no furo 23 na porção leste, sendo a média geral de $30,86 \%$ (Figura 4).

A mineralização em Autazes distribui-se por uma área de $155 \mathrm{~km}^{2}$, em dois domínios distintos: um a norte e outro a sul. O domínio norte tem formato ovalado, com eixo ligeiramente maior na direção nordestesudoeste, parcialmente subdividido em duas sub feições positivas menores por uma zona não mineralizada de orientação noroeste-sudeste, que se estende do furo 32 ao furo 07. Os limites do Depósito na porção sul são bem estabelecidos, com furos laterais de teores marginais (furos 05 e 10) e estéreis, assim como os limites a noroeste, nos furos 29, 30 e 31 . Os limites norte, nordeste e leste do depósito ainda representam fronteiras de expansão da mineralização, com furos de teores e espessuras significativas (Figura 4).
Quanto à distribuição espacial do corpo mineralizado, os resultados obtidos apontam para uma equivalência entre espessura e teor, com as maiores espessuras e os mais elevados teores coincidindo na porção norte do depósito. Tal correspondência não ocorre na porção estreita do corpo mineralizado a sul, o qual, apesar dos elevados teores, apresenta espessuras menos expressivas (Figura 4).

\section{Mineralogia e geoquímica da mineralização}

As fases minerais presentes no Depósito de Autazes foram determinadas a partir dos resultados das análises químicas e da difratometria de raios-X (DRX). A partir dos resultados obtidos em cada intervalo mineralizado intersectado, foi possível estabelecer a concentração média total das principais fases minerais para o depósito (Tabela 2). Tais concentrações representam o produto da associação entre a recomposição mineralógica normativa, obtida com os resultados químicos, e a validação das fases minerais presentes, por meio das determinações mineralógicas semiquantitativas por DRX.

Tabela 2. Mineralogia normativa do Depósito de Autazes (Potássio do Brasil, 2014).

\begin{tabular}{ccc}
\hline Compostos & Fases Minerais & Composição Média \% \\
\hline $\mathrm{KCl}$ & Silvita & 30,86 \\
$\mathrm{NaCl}$ & Halita & 56,24 \\
$\mathrm{MgSO}_{4}$ & Kieserita & 0,91 \\
$\mathrm{~K}_{2} \mathrm{SO}_{4}$ & Polyalita, Langbeinita, Kainita & 1,45 \\
$\mathrm{MgCl}_{2}$ & Carnalita & 0,01 \\
$\mathrm{CaSO}_{4}$ & Anidrita & 6,91 \\
Insolúveis & Argilominerais e quartzo & 3,36 \\
\hline
\end{tabular}

\section{Estratigrafia da mineralização}

Em face dos resultados apresentados, o Depósito de Autazes foi subdividido em três horizontes estratigráficos, com características petrográficas, mineralógicas e químicas distintas, denominados, da base para o topo, como: 1) Intervalo Mineralizado Inferior, rico em silvinita branca; 2) Intervalo Mineralizado Intermediário, rico em sulfatos; 3) Intervalo Mineralizado Superior, rico em Silvinita Vermelha (Potássio do Brasil, 2014) (Figura 5). As diferenças de cada intervalo mineralizado são apresentadas a seguir. Intervalo Mineralizado Inferior

O Intervalo Mineralizado Inferior do Depósito de Autazes é constituído predomi- nantemente por silvinitas brancas leitosas, de granulação fina a média, laminadas, em contato gradacional com o Intervalo Mineralizado Intermediário no topo e, na base, com um espesso pacote de halitas finas laminadas. Também na base ocorrem interlaminações de halita transparente, gradativamente mais espessas, alternadas com lâminas de silvita e, no topo do intervalo, ocorrem silvinitas de coloração rosa, laminadas, contendo sulfatos de magnésio e potássio como kieserita e kainita, respectivamente.

Em relação à concentração das fases minerais presentes, o intervalo inferior é caracterizado pelo predomínio de cloretos (halitas e silvitas), 
seguidos por anidritas e sulfatos de magnésio e argilominerais insolúveis e traços de cloreto de potássio (kieserita e kainita), além de magnésio (carnalita) (Tabela 3).

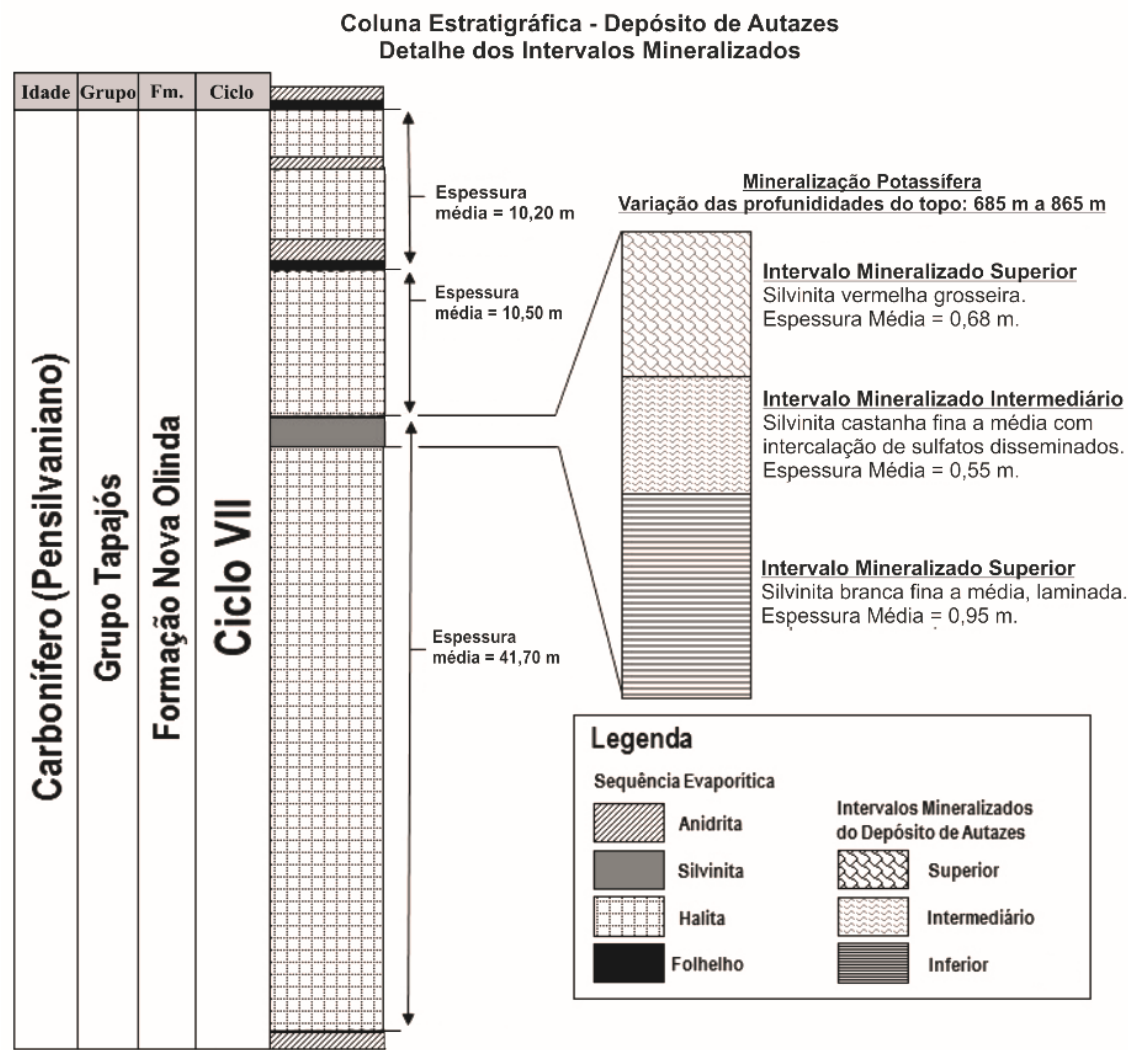

Figura 5 - Coluna estratigráfica de detalhe dos intervalos mineralizados do Depósito de Autazes, conforme descrição das sondagens (modificado de Potássio do Brasil, 2014).

Tabela 3. Concentração normativa das fases minerais presentes no Intervalo Mineralizado Inferior do Depósito de Autazes (modificado de Potássio do Brasil, 2014).

\begin{tabular}{ccccccccc}
\hline Furo & $\mathbf{N a C l} \%$ & $\mathbf{~ K C l \%}$ & $\mathbf{C a S O}_{\mathbf{4}} \%$ & $\mathbf{M g S O}_{\mathbf{4}} \%$ & $\mathbf{K}_{\mathbf{2}} \mathbf{S O}_{\mathbf{4}} \%$ & $\mathbf{M g C l}_{\mathbf{2}} \%$ & Insolúveis\% & Total\% \\
\hline $\mathbf{2}$ & 45,76 & 41,08 & 8,37 & 0,41 & 1,81 & 0,00 & 2,18 & 99,60 \\
$\mathbf{3}$ & 79,59 & 11,87 & 5,66 & 0,03 & 1,06 & 0,00 & 1,87 & 100,07 \\
$\mathbf{5}$ & 90,36 & 4,40 & 3,90 & 0,03 & 0,93 & 0,00 & 1,41 & 101,04 \\
$\mathbf{9}$ & 54,14 & 37,62 & 2,44 & 2,31 & 1,54 & 0,00 & 0,80 & 98,85 \\
$\mathbf{1 0}$ & 84,01 & 8,58 & 2,28 & 2,14 & 1,50 & 0,00 & 0,37 & 98,88 \\
$\mathbf{1 2}$ & 63,70 & 30,34 & 4,99 & 0,25 & 0,45 & 0,00 & 0,29 & 100,03 \\
$\mathbf{1 5}$ & 48,23 & 32,76 & 6,34 & 4,36 & 3,92 & 0,00 & 2,23 & 97,84 \\
$\mathbf{1 6}$ & 63,10 & 32,26 & 3,54 & 0,19 & 1,02 & 0,00 & 0,17 & 100,29 \\
$\mathbf{1 7}$ & 66,76 & 27,08 & 2,86 & 1,35 & 0,83 & 0,00 & 0,21 & 99,09 \\
$\mathbf{1 9}$ & 87,23 & 6,46 & 3,59 & 0,73 & 1,39 & 0,00 & 0,28 & 99,69 \\
$\mathbf{2 0}$ & 59,41 & 31,68 & 2,97 & 2,43 & 2,02 & 0,00 & 0,63 & 99,14 \\
$\mathbf{2 1}$ & 87,18 & 6,35 & 4,86 & 0,08 & 0,92 & 0,00 & 0,90 & 100,30 \\
$\mathbf{2 3}$ & 42,34 & 51,13 & 3,43 & 1,07 & 1,68 & 0,00 & 0,33 & 99,97 \\
$\mathbf{2 6}$ & 63,28 & 29,37 & 2,78 & 2,05 & 0,41 & 0,00 & 0,75 & 98,65 \\
$\mathbf{2 8}$ & 67,28 & 24,88 & 3,57 & 1,63 & 1,61 & 0,00 & 0,49 & 99,45 \\
$\mathbf{3 3}$ & 58,27 & 33,91 & 2,06 & 3,72 & 0,33 & 0,04 & 0,44 & 98,77 \\
$\mathbf{3 4}$ & 81,29 & 10,07 & 5,73 & 1,31 & 0,05 & 0,05 & 0,40 & 98,89 \\
$\mathbf{3 5}$ & 57,13 & 33,47 & 6,82 & 0,14 & 1,78 & 0,00 & 0,95 & 100,30 \\
\hline
\end{tabular}


O Intervalo Mineralizado Inferior foi identificado em todos os 18 furos mineralizados considerados para o Depósito de Autazes, com espessuras que variam de 0,62 m no furo 19 a $1,43 \mathrm{~m}$ no furo 35 . Os teores de $\mathrm{KCl}$, por sua vez, variam de $4,40 \%$ no furo 03 a $51,13 \%$ no furo 23 .

No setor nordeste do depósito o Intervalo Mineralizado Inferior apresenta o maior teor médio de $\mathrm{KCl}$ (32,15\%), que varia de 10,07\% no furo 34 , até $51,13 \%$ no furo 23 . A espessura média do intervalo nesse setor é de $0,91 \mathrm{~m}$, variando de $0,69 \mathrm{~m}$ no furo 23 , até $1,43 \mathrm{~m}$ no furo 35. A mineralização no setor é composta por variações de silvinita branca leitosa, translúcida a opaca, com textura nodular, sacaroidal a laminada fina e silvinita alaranjada intensa à rósea, opaca a translúcida, com textura sacaroidal a laminada fina a média. Em menor quantidade há sulfatos disseminados, que tendem a aumentar em concentração em direção ao extremo nordeste do depósito (Figura 6).

No setor noroeste do depósito, o Intervalo Mineralizado Inferior apresenta um teor médio de $\mathrm{KCl}$ de $23,71 \%$, com mínimo de 6,35\% no furo 21 a norte e máximo de 32,76\% no furo 15 , na porção centro-sul. A espessura média do intervalo é de 1,05 m, com variações de $0,58 \mathrm{~m}$ no furo 15, até $1,37 \mathrm{~m}$ no furo 26. A mineralização no setor é composta por silvinita branca leitosa com porções ou bandas de coloração alaranjada a rósea, além de lâminas de coloração cinza clara, translúcidas a opacas. A textura dos litotipos é extremamente fina e laminada.

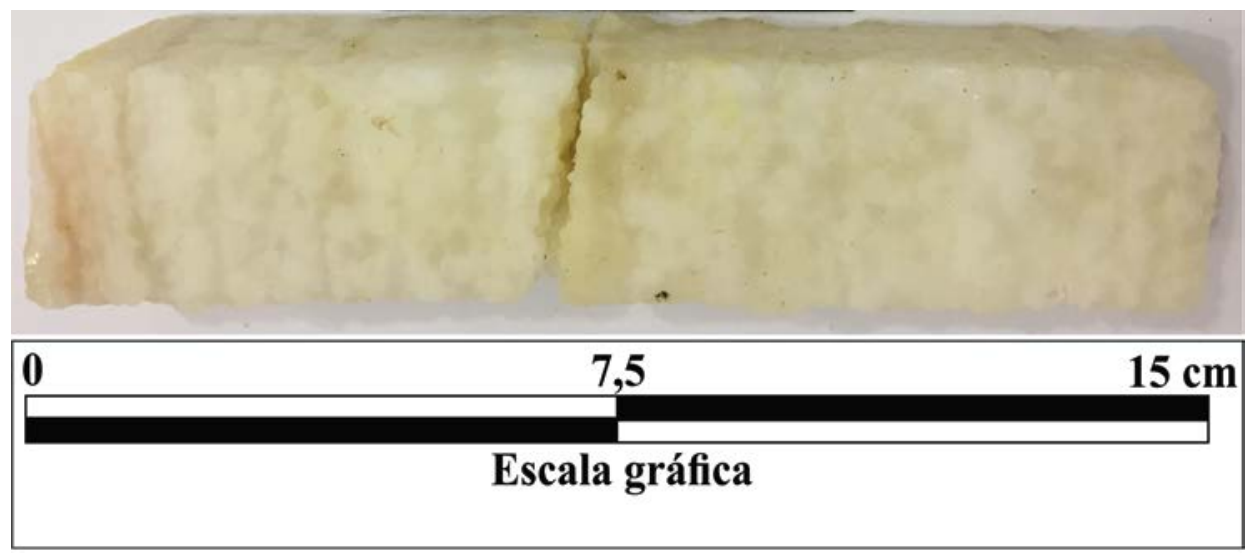

Figura 6 - Amostra do Intervalo Mineralizado Inferior na porção nordeste do Depósito de Autazes: silvinita branca leitosa, opaca, nodular. Furo 35, profundidades: 770,16 m a 770,31 m (modificado de Potássio do Brasil, 2014).

No setor sul do depósito o Intervalo Mineralizado Inferior apresenta um teor médio de $\mathrm{KCl}$ de 26,58\%, com mínimo de $4,40 \%$ no furo 03 , no extremo sul, até um máximo de $41,08 \%$ no furo 02 , na porção centro-norte do setor. A espessura média do intervalo no setor é de $1,13 \mathrm{~m}$, com extremos de $0,66 \mathrm{~m}$ no furo 02 e de $1,28 \mathrm{~m}$ furo 12 . A mineralização é composta por silvinita branca a cinza clara, com níveis castanhos a avermelhados ou róseos, translúcida a opaca, com intercalações de lâminas de sulfatos esbranquiçados e halita com textura variando de laminada fina a sacaroidal (Potássio do Brasil, 2014).

Intervalo Mineralizado Intermediário

O Intervalo Mineralizado Intermediário é constituído predominantemente por silvinitas que variam de coloração alaranjada a vermelha, até tons castanhos acinzentados. A granulação é média a grossa, com cristais bem desenvolvidos e texturas que variam de maciças a laminadas, com lâminas e redes de sulfatos cinza claros disseminados. $\mathrm{Na}$ base ocorrem silvinitas de coloração alaranjada a avermelhada, opacas a translúcidas, com intercalações de lâminas de sulfatos esbranquiçados, em contato gradacional com os litotipos do intervalo inferior. No topo o contato também é gradacional e ocorre entre silvinitas de coloração vermelha a levemente esbranquiçada, com tons castanhos, com as silvinitas vermelhas do intervalo mineralizado superior.

A concentração das fases minerais presentes no intervalo intermediário é caracterizada pelo predomínio de cloretos (halitas e silvinitas). As anidritas também são abundantes, com ocorrências de sulfatos de potássio e magnésio (kainita e kieserita), argilominerais insolúveis e traços de cloreto de magnésio (carnalita) (Tabela 4). 
Tabela 4. Concentração normativa das fases minerais presentes no Intervalo Mineralizado Intermediário do Depósito de Autazes (modificado de Potássio do Brasil, 2014).

\begin{tabular}{|c|c|c|c|c|c|c|c|c|}
\hline Furo & $\mathrm{NaCl} \%$ & KCl\% & $\mathrm{CaSO}_{4} \%$ & $\mathrm{~K}_{2} \mathrm{SO}_{4} \%$ & $\mathrm{MgSO}_{4} \%$ & $\mathrm{MgCl}_{2} \%$ & Insolúveis\% & Total\% \\
\hline 2 & 44,71 & 49,57 & 3,43 & 0,32 & 0,05 & 0,00 & 1,40 & 99,48 \\
\hline 9 & 40,09 & 39,72 & 16,34 & 1,98 & 0,02 & 0,00 & 2,49 & 100,64 \\
\hline 12 & 43,57 & 52,02 & 3,72 & 0,24 & 0,12 & 0,00 & 0,20 & 99,87 \\
\hline 15 & 30,52 & 29,37 & 14,88 & 4,67 & 3,52 & 0,00 & 15,35 & 98,31 \\
\hline 16 & 27,10 & 19,15 & 18,30 & 3,49 & 0,02 & 0,00 & 32,30 & 100,37 \\
\hline 17 & 32,32 & 40,81 & 13,13 & 1,62 & 0,05 & 0,00 & 12,37 & 100,29 \\
\hline 19 & 54,86 & 28,64 & 8,80 & 1,47 & 0,05 & 0,00 & 5,39 & 99,21 \\
\hline 20 & 27,78 & 33,67 & 15,20 & 3,68 & 0,10 & 0,00 & 20,23 & 100,67 \\
\hline 21 & 36,45 & 27,95 & 16,56 & 2,90 & 0,05 & 0,00 & 16,59 & 100,50 \\
\hline 23 & 34,81 & 36,91 & 13,75 & 3,55 & 0,22 & 0,00 & 11,35 & 100,59 \\
\hline 26 & 38,86 & 35,42 & 10,70 & 2,24 & 0,70 & 0,00 & 11,80 & 99,72 \\
\hline 28 & 42,17 & 51,07 & 4,90 & 1,08 & 0,08 & 0,00 & 0,58 & 99,89 \\
\hline 33 & 43,45 & 32,14 & 7,22 & 1,54 & 6,38 & 0,12 & 6,49 & 97,34 \\
\hline 35 & 34,08 & 44,43 & 12,77 & 3,84 & 0,48 & 0,00 & 5,00 & 100,60 \\
\hline
\end{tabular}

O Intervalo Mineralizado Intermediário foi intersectado em 14 dos 18 furos mineralizados considerados para o Depósito de Autazes com espessuras que variam de $0,30 \mathrm{~m}$ no furo 12 a $1,40 \mathrm{~m}$ no furo 26 . Os teores de $\mathrm{KCl}$ oscilam entre $19,15 \%$ no furo 16 a 52,02\% no furo 02 .

No setor nordeste do depósito, o Intervalo Mineralizado Intermediário apresenta um teor médio de $\mathrm{KCl}$ de 37,83\%, com um mínimo de $32,14 \%$ no furo 33 e máximo de $44,43 \%$ no furo 35. A espessura média do intervalo no setor é de $0,73 \mathrm{~m}$, com extremos de $0,55 \mathrm{~m}$ no furo 35 , até $0,98 \mathrm{~m}$ no furo 33. A mineralização é composta por silvinita avermelhada a alaranjada com finas lâminas esbranquiçadas de halita, translúcida a opaca, textura laminada e granulometria fina a média. Também são frequentes disseminações de material sulfatado de coloração acinzentada e/ou azulada, preenchendo os espaços intersticiais, com textura em rede ou esqueletal (Szatmari et al, 2008; Warren, 2006).

No setor noroeste o Intervalo Mineralizado Intermediário apresenta um teor médio de $\mathrm{KCl}$ de $30,72 \%$ e extremos entre $19,15 \%$ a $40,81 \%$ nos furos 16 e 17, respectivamente. A espessura média do intervalo no setor é de $0,60 \mathrm{~m}$, com um mínimo de 0,32 m no furo 21 e máximo de $1,40 \mathrm{~m}$ no furo 26. A mineralização é composta por silvinita de coloração cinza azulada a castanha, a avermelhada ou alaranjada, translúcida a opaca, com granulação média a grossa. A textura dos litotipos varia entre laminada a maciça, com redes e/ou lâminas enterolíticas de sulfatos, além de bandas e cristais grosseiros de halitas disseminados.

No setor sul do depósito, o Intervalo Mineralizado Intermediário apresenta o teor médio mais rico em cloreto de potássio, com 48,09\%, distribuído de forma regular por todas as regiões, desde um mínimo de 39,72\% no furo 09, no extremo sul, até um máximo de 51,07\% no furo 28, na porção norte. A espessura também acompanha essa regularidade, porém confere ao setor a menor média para o intervalo intermediário, com $0,33 \mathrm{~m}$ e extremos entre $0,30 \mathrm{~m}$ no furo 12 e $0,40 \mathrm{~m}$ no furo 02 . A mineralização no setor é composta por silvinita alaranjada a castanha esbranquiçada, opaca a translúcida, granulação fina a média, textura laminada com intercalações de lâminas e/ou redes de sulfatos de coloração acinzentada e bandas e cristais grosseiros de halitas disseminados (Figura 7) (Potássio do Brasil, 2014).

\section{Intervalo Mineralizado Superior}

O Intervalo Mineralizado Superior do Depósito de Autazes é constituído predominantemente por silvinitas de coloração vermelha, com bandas esbranquiçadas, translúcidas a opacas e de granulação grosseira. Também são frequentes as ocorrências de redes ou lâminas enterolíticas (Szatmari et al, 2008; Warren, 2006) de sulfatos acinzentados preenchendo os espaços 


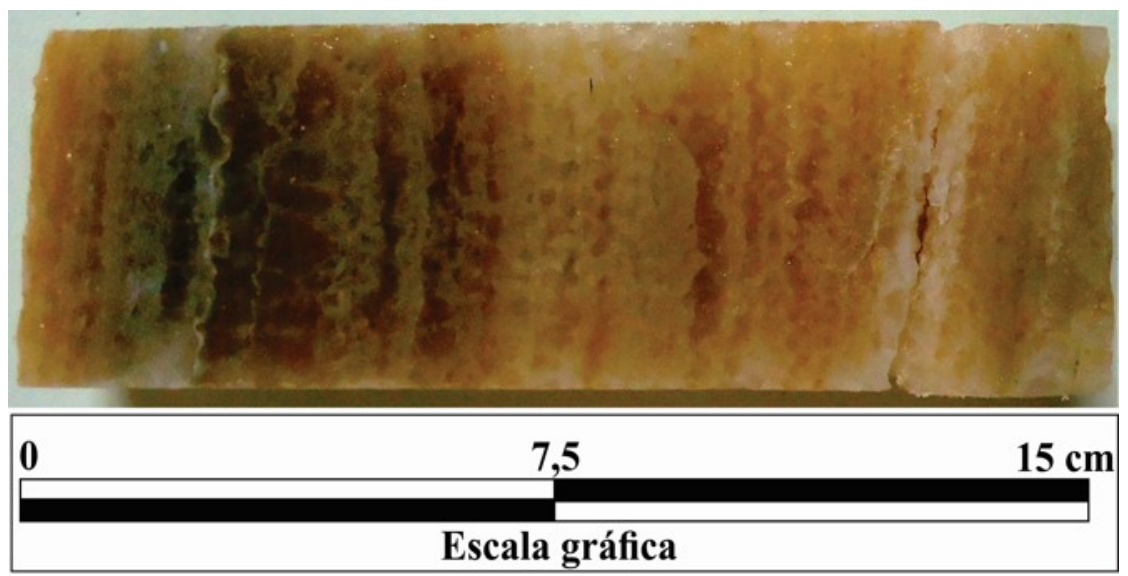

Figura 7 - Amostra do Intervalo Mineralizado Intermediário na porção sul do Depósito de Autazes. Silvinita alaranjada, opaca, granulação média, textura laminada, com alternância de lâminas sulfatadas brancas a castanha acinzentadas. Furo 12, profundidades: 824,23 m a 824,38 m (modificado de Potássio do Brasil, 2014).

Tabela 5. Concentração normativa das fases minerais presentes no Intervalo Mineralizado Superior do Depósito de Autazes (modificado de Potássio do Brasil, 2014).

\begin{tabular}{ccccccccc}
\hline Furo & $\mathbf{N a C l} \%$ & $\mathbf{K C l} \%$ & $\mathbf{C a S O}_{\mathbf{4}} \%$ & $\mathbf{K}_{\mathbf{2}} \mathbf{S O}_{\mathbf{4}} \%$ & $\mathbf{M g S O}_{\mathbf{4}} \%$ & $\mathbf{M g C l}_{\mathbf{2}} \%$ & Insolúveis\% & Total\% \\
\hline $\mathbf{2}$ & 33,10 & 25,59 & 31,70 & 0,33 & 0,10 & 0,00 & 9,05 & 99,86 \\
$\mathbf{3}$ & 47,30 & 41,61 & 7,43 & 1,32 & 0,03 & 0,00 & 2,21 & 99,91 \\
$\mathbf{9}$ & 32,94 & 38,79 & 20,81 & 2,54 & 0,02 & 0,00 & 5,27 & 100,37 \\
$\mathbf{1 2}$ & 37,77 & 52,06 & 8,18 & 0,59 & 0,04 & 0,00 & 1,45 & 100,10 \\
$\mathbf{1 5}$ & 57,64 & 34,54 & 6,05 & 1,52 & 0,04 & 0,00 & 0,53 & 100,32 \\
$\mathbf{1 6}$ & 53,97 & 23,10 & 14,13 & 3,16 & 0,03 & 0,00 & 6,39 & 100,78 \\
$\mathbf{1 7}$ & 50,12 & 45,13 & 3,79 & 0,51 & 0,05 & 0,00 & 0,33 & 99,93 \\
$\mathbf{1 9}$ & 49,44 & 37,49 & 8,98 & 1,47 & 0,06 & 0,00 & 2,23 & 99,67 \\
$\mathbf{2 0}$ & 62,87 & 30,60 & 4,14 & 0,93 & 0,07 & 0,00 & 1,55 & 100,16 \\
$\mathbf{2 1}$ & 75,77 & 20,31 & 3,26 & 0,53 & 0,05 & 0,00 & 0,27 & 100,19 \\
$\mathbf{2 3}$ & 51,65 & 42,48 & 4,42 & 0,98 & 0,03 & 0,00 & 0,69 & 100,26 \\
$\mathbf{2 6}$ & 54,09 & 35,03 & 8,03 & 0,93 & 0,03 & 0,00 & 2,71 & 100,82 \\
$\mathbf{2 8}$ & 33,61 & 44,06 & 10,35 & 2,23 & 0,02 & 0,00 & 10,37 & 100,64 \\
$\mathbf{3 3}$ & 55,75 & 33,28 & 5,86 & 0,06 & 0,01 & 0,04 & 4,90 & 99,89 \\
$\mathbf{3 4}$ & 77,44 & 9,13 & 8,00 & 0,48 & 0,13 & 0,01 & 4,92 & 100,12 \\
$\mathbf{3 5}$ & 51,77 & 30,62 & 11,77 & 2,63 & 0,05 & 0,00 & 3,48 & 100,32 \\
\hline
\end{tabular}

intersticiais. Similar aos demais intervalos inferiores, as fases minerais presentes no intervalo superior caracterizam-se pelo predomínio de cloretos (halitas e silvinitas), seguidos por anidritas e sulfatos de potássio e magnésio (kainita e kieserita) disseminados, além de argilo-minerais insolúveis e traços de cloreto de magnésio (carnalita) (Tabela 5).

O Intervalo Mineralizado Superior foi intersectado em 16 dos 18 furos mineralizados considerados para o Depósito de Autazes, apresentando espessuras que variam de $0,23 \mathrm{~m}$ no furo 16 a $1,16 \mathrm{~m}$ no furo 23 . Os teores de $\mathrm{KCl}$ variam de $9,13 \%$ no furo 34 a 52,06 \% no furo 12.

No setor nordeste do depósito o Intervalo Mineralizado Superior apresenta um teor médio de $\mathrm{KCl}$ de 28,88\%, com um mínimo de 9,13\% no furo 34 e máximo de $42,48 \%$ no furo 23 . A espessura média é de $0,91 \mathrm{~m}$, com extremos de $0,52 \mathrm{~m}$ no furo 34 e 1,16 metros no furo 23. A mineralização é composta por silvinitas de coloração vermelha a esbranquiçada, translúcidas a opacas, com cristais de granulação fina a grossa, envolvidos por películas de óxidos de ferro, além de redes e lâminas enterolíticas de sulfatos cinza claros preenchendo os espaços intersticiais, e intercalações de halitas brancas, translúcidas.

No setor noroeste do depósito o intervalo superior apresenta um teor médio de $\mathrm{KCl}$ de $32,31 \%$ e variações de $20,31 \%$ no furo 21 , até $45,13 \%$ furo 17 . A espessura média é de $0,67 \mathrm{~m}$, com um mínimo de 0,23 m no furo 16 e máximo 
de $0,86 \mathrm{~m}$ no furo 19. A mineralização é composta por silvinitas vermelhas com bandas esbranquiçadas, translúcidas a opacas, com granulação grosseira. São também frequentes ocorrências de bandas acinzentadas grosseiras e faixas esbranquiçadas de halita, além de redes e lâminas enterolíticas de sulfatos acinzentados disseminados.

No setor sul do Depósito de Autazes o Intervalo Mineralizado Superior apresenta o teor médio mais rico de cloreto de potássio (40,42\%), que varia de um mínimo de $25,59 \%$ no furo 02 até um máximo de 52,06\% no furo
12, na porção centro norte. A distribuição das espessuras também acompanha essa irregularidade e confere ao setor a menor média geral entre todas as do intervalo superior, com $0,51 \mathrm{~m}$ e extremos que variam entre $0,40 \mathrm{~m}$ no furo 02 e 0,64 m no furo 03. A mineralização é composta por silvinitas vermelhas a alaranjadas, translúcidas a opacas, com granulometria fina a média e textura laminada com intercalações de lâminas sulfatadas enterolíticas de coloração cinza, regularmente espaçadas, além de bandas de cristais de halita grosseiros disseminados (Figura 8) (Potássio do Brasil, 2014).

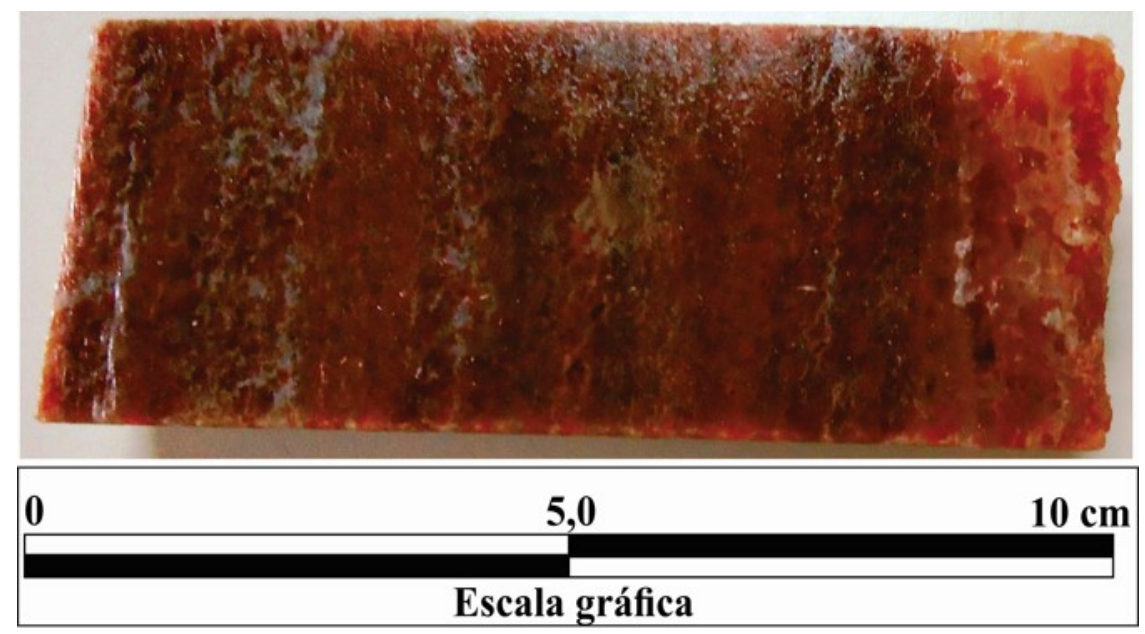

Figura 8 - Amostra do Intervalo Mineralizado Superior na porção sul do Depósito de Autazes. Silvinita vermelha intensa, opaca, granulometria média, textura laminada, com lâminas sulfatadas de tons cinza a brancos. Furo 12, profundidades: 823,59 m a 823,72 m (modificado de Potássio do Brasil, 2014).

\section{CONCLUSÕES}

O Depósito Potassífero de Autazes compreende um horizonte subhorizontal de minerais evaporíticos inseridos na porção superior da Formação Nova Olinda, da Sequência Pensilvaniana-Permiana da Bacia do Amazonas. A partir do programa de sondagens da Potássio do Brasil, foi possível definir a estratigrafia, delimitar o corpo mineralizado, avaliar a distribuição das espessuras e teores do depósito mineral. A amostragem permitiu significativo estudo químico, mineralógico e petrográfico. Estes dados inéditos, aqui apresentados, possibilitaram a divisão da mineralização em três horizontes ou intervalos, denominados, da base para o topo: 1) Intervalo Mineralizado Inferior, com predomínio de silvinitas brancas, finas e laminadas; 2) Intervalo Mineralizado Intermediário, que apresenta principalmente silvinita castanha e sulfatos disseminados; 3) Intervalo Mineralizado Superior, constituído por silvinitas avermelhadas, com granulação grosseira. As texturas das fácies evaporíticas apontam para um caráter deposicional primário da mineralização, em especial das silvinitas brancas laminadas finas do intervalo inferior.

As caracterizações faciólogicas da mineralização potassífera do Depósito de Autazes, aqui empreendidas, abrem perspectivas para abordagens mais amplas e atualizadas para a evolução deposicional das sucessões evaporíticas da Bacia do Amazonas. Tais análises encontram paralelo nos trabalhos propostos para análises estratigráficas de sequências de sucessões carbonáticasevaporíticas desenvolvidos, principalmente, por Kendall (1988, 1992, 2010); Tucker (1991); Warren (2006, 2016) e Catuneanu et al (2011).

A pesquisa mineral desenvolvida pela Potássio do Brasil e sintetizada aqui, identificou ainda uma reserva geológica total superior a 767 Mt e teor médio de $30,71 \%$ de $\mathrm{KCl}$, com 2,07 m de espessura média, entre as 

descoberta abre perspectiva para aprovei- futuro próximo.

\section{AGRADECIMENTOS}

Os autores agradecem à Potássio do Brasil Ltda. pela liberação dos dados inéditos do Projeto Potássio Amazonas na região de Autazes-AM, que permitiram a realização deste estudo, e ao Instituto de Geociências da Universidade Federal de Minas Gerai (IGC-UFMG), por meio do apoio do Programa de Pós-Graduação em Geologia.

\section{REFERÊNCIAS}

ALMEIDA, F.F.M. \& HASUI, Y. O Pré-Cambriano do Brasil. São Paulo: Blücher, 378p., 1984.

AIRES, J.R. Estudo do vulcanismo básico da Bacia Amazônica. Rio de Janeiro: Petrobras-Cenpes, 61p. (Rel. 478)., 1983.

AGAPITO ASSOCIATES, INC. Technical Report Concerning Mineral and Resource Estimates, Fazendinha and Ararí Deposits, Amazonas, Brazil. Grand Junction: Agapito, 57p., 2008.

BIZZI, L.A.; SCHOBBENHAUS, C.; VIDOTI, R.M.; GONÇALVES, J.H. (Eds.), Geologia, Tectônica e Recursos Minerais do Brasil. Brasília: CPRM, Serviço Geológico do Brasil, 643 p., 2004.

CAMPOS, J.N.P. \& TEIXEIRA, L.B. Estilos tectônicos da Bacia do Amazonas. In: CONGRESSO BRASILEIRO DE GEOLOGIA, 35, 1988, Belém. Anais. São Paulo: Sociedade Brasileira de Geologia, 1988. v. 5, p. 2161-2172.

CAPUTO, M.V.; RODRIGUES, R.; VASCONCELOS, D.N.N. Nomenclatura estratigráfica da Bacia do Amazonas: histórico e atualização. In: CONGRESSO BRASILEIRO DE GEOLOGIA, 26, 1972, Belém. Anais. São Paulo: Sociedade Brasileira de Geologia, 1972. v. 3, p. 35-46.

COSTA, M.G.F. Fácies deposicionais e ambientes de sedimentação da Formação Monte Alegre (neocarbonífero) na área de Autás Mirim e adjacências, Bacia do Médio Amazonas. Recife, 1984. 90p. il. Tese (Mestrado) Universidade Federal de Pernambuco.

COSTA, A.R.A. \& WANDERLEY FILHO, J.R. Os evaporitos e halocinese na Amazônia. In: MOHRIAK, W.; SZATMARI, P.; ANJOS, S.M.C. (Org.), Sal: Geologia e Tectônica. São Paulo: Ed. Beca, p. 210-221, 2009.

CPRM - COMPANHIA DE PESQUISA DE RECURSOS MINERAIS - SERVIÇO GEOLÓGICO DO BRASIL. Carta Geológica do Brasil ao Milionésimo. Escala 1:1.000.000. Sistema de Informações Geográficas. Programa Geologia do Brasil. Brasília: CPRM. CD-ROM, 2004.

CUNHA, P.R.C.; GONZAGA, F.G.; COUTINHO, L.F.C.; FEIJÓ, F.J. Bacia do Amazonas. B. Geoci. Petrobras, Rio de Janeiro, v. 8, n. 1, p. 47-55, 1994.

CUNHA, P.R.C. Análise estratigráfica dos sedimentos Eo/Mesodevonianos da porção ocidental da Bacia do Amazonas sob a ótica da estratigrafia de sequências no interior cratônico. Porto Alegre, 2000. 248p. Dissertação (Mestrado) - Instituto de Geociências, Universidade Federal do Rio Grande do Sul.

CUNHA, P.R.C.; MELO, J.H.G.; SILVA, O.B. Bacia do Amazonas. B. Geoci. Petrobras, Rio de Janeiro, v. 15, n. 2, p. 227-251, 2007.

DARDENNE, M.A. \& SCHOBBEnHAUS, C. Metalogênese do Brasil. Brasília: Editora Universidade de Brasília, 392p., 2001.

DIAS, V.P. \& FERNANDES, E. Fertilizantes: Uma visão global sintética. In: BNDES - Banco Nacional de Desenvolvimento Econômico e Social. BNDES Setorial, Rio de Janeiro, v. 24, p. 97-138, 2006.

KENDALL. A. C. Aspects of evaporite basin stratigraphy, in B. C. Schreiber, eds., Evaporites and hydrocarbons: New York, Columbia University Press, p. 11-65, 1988.
KENDALL. A. C. Evaporites, in R. G. Walker, and N. P. James, eds., Facies Models: Responses to sea level change, Geological Association of Canada, p. 375-409, 1992.

KENDALL. A. C. Marine evaporites, in James, N. P., and Dalrymple, R. W., eds., Facies Models 4: St. Johnhs, Newfoundland, and Labrador, Canada, Geological Association of Canada, p. 505-539, 2010.

KULAIF, Y. \& GÓES, A.M. Potássio no Brasil. In: MELFI, A.J.; MISI, A.; CAMPOS, D.A.; CORDANI, U.G. (Org.), Recursos Minerais no Brasil: problemas e desafios. Rio de Janeiro: Academia Brasileira de Ciências. p. 84-95, 2016.

LEMOS, V.B. Assembléias de conodontes do carbonífero da Bacia do Amazonas. Porto Alegre, 1990. 259p. Tese (Doutorado em Ciências) - Instituto de Geociências, Universidade Federal do Rio Grande do Sul.

MARINI, O. Potencial Mineral do Brasil. In: MELFI, A.J.; MISI, A.; CAMPOS, D.A.; CORDANI, U.G. (Org.), Recursos Minerais no Brasil: problemas e desafios. Rio de Janeiro: Academia Brasileira de Ciências. p. 18-31, 2016.

NEVES, C.A.O. Prospectos potenciais e áreas prioritárias para exploração na bacia do Amazonas. Bol. Geociencias da Petrobras, 4 (1): 95-103, 1990

NEVES, C.A.O.; CAMPOS, J.N.P.; ARANA, J.; TEIXEIRA, L.B.; RODRIGUES, R.; TRIGÜIS, J.A. Integração Geológica e Exploratória da Bacia do Amazonas. Manaus: Petrobras/Depex, Relatório Interno, 113p., 1989.

PLAYFORD, G. \& DINO, R. Palynostratigraphy of upper Palaeozoic strata (Tapajós Group), Amazonas Basin, Brazil. Palaeontographica. Abt. B. Palaeophytologie, Stuttgart, n. 255, p. 1-46, 2000.

POTÁSSIO DO BRASIL. Relatório Final Positivo Único de Pesquisa, Sais de Potássio, Municípios de Autazes e Itacoatiara, Amazonas. Belo Horizonte: Potássio do Brasil, 286p., 2014.

SAD, A.R.; CAMPOLINA, A.; COSTA, A.M.; LIMA, F.R.T.; CARVALHO, R.S. Depósito de Potássio de Fazendinha, Nova Olinda do Norte, Amazonas. In: SCHOBBENHAUS C.; QUEIROZ, E.T.; COELHO, C.E.S. (Coords.), Principais Depósitos Minerais do Brasil. Brasília: DNPM-CPRM, v. IV-C, p. 257-276, 1997.

SAD, A.R.; LIMA, F.R.T.; WOLF, F.; SOARES, J.A.M.; CARVALHO, R.S. Depósito Potassífero da Fazendinha Bacia do Médio Amazonas. In: CONGRESSO BRASILEIRO DE GEOLOGIA, 32, 1982, Salvador. Anais. São Paulo: Sociedade Brasileira de Geologia, 1982. v. 3, p. 1086-1099.

SANTOS, J.O.S. Geotectônica dos escudos das Guianas e Brasil Central. In: BIZZI, L.A.; SCHOBBENHAUS, C.; VIDOTI, R.M.; GONÇALVES, J.H. (Eds.), Geologia, Tectônica e Recursos Minerais do Brasil. Brasília: CPRM, Serviço Geológico do Brasil. p. 169-226, 2003.

SZATMARI, P; SIMÕES, I.A.; CARVALHO, R.S. Evaporitos da Bacia do Amazonas. Rio de Janeiro: Petrobras, Relatório Interno, 128 p., 1975.

SZATMARI, P; TIBANA, P; SIMÕES, I.A.; CARVALHO; R.S.; LEITE, D.C. Atlas Petrográfico dos Evaporitos. In: MOHRIAK, W.; SZATMARI, P.; ANJOS, S.M.C. (Org.), Sal: Geologia e Tectônica. São Paulo: Ed. Beca, p. 42-63, 2008. 
TASSINARI, C.C.G. \& MACAMBIRA, M.J.B. A evolução do Cráton Amazônico. In: MANTESSO-NETO, V.; BARTORELLI, A.; CARNEIRO, C. D. R.; BRITO-NEVES, B.B. (Eds.), Geologia do Continente Sul-Americano: Evolução da obra de Fernando Flávio Marques de Almeida. São Paulo: Ed. Beca, p. 471-485, 2004.

THOMAZ FILHO, A.; CORDANI, U.G.; MARINO, O. Idades $\mathrm{K}-\mathrm{Ar}$ de rochas basálticas da Bacia Amazônica e sua significação tectônica regional. In: CONGRESSO BRASILEIRO DE GEOLOGIA, 28, 1974, Porto Alegre. Anais. São Paulo: Sociedade Brasileira de Geologia, v. 6, p. 273-278, 1974.

TUCKER, M. E. Sequence stratigraphy of carbonateevaporite basins, models and application to the UpperPermian (Zechstein of northeast England and adjoiningNorth Sea. Journal of the Geological Society. v. 148,p. 1019-1036, 1991.

UHLEIN, A.; PAIM, P.S.G.; TASSINARI, C.C.G.; PEDREIRA, A.J. Análise Estratigráfica de Bacias Rifte PaleoMesoproterozóicas dos Crátons Amazônico e São Francisco, Brasil. Geonomos, Belo Horizonte, v.23, n.2, p. 1-13, 2015.

WARREN, J.K. Evaporites: Sediments, Resources and Hydrocarbons. Berlin: Springer-Verlag, 1035 p., 2006.

WARREN, J. K. Evaporites: A compendium (ISBN 9783-31913511-3): Berlin, Springer, 1854 p, 2016.
YAMAMOTO, J.K. 2001. Avaliação e classificação de reservas minerais. São Paulo: Editora da Universidade de São Paulo, 232p., 2001.

ZALÁN, P. V. Evolução fanerozóica das bacias sedimentares brasileiras. In: MANTESSO-NETO, V.; BARTORELLI, A.; CARNEIRO, C. D. R.; BRITO-NEVES, B.B. (Eds.), Geologia do Continente Sul-Americano: Evolução da obra de Fernando Flávio Marques de Almeida. São Paulo: Ed. Beca, p. 595-612, 2004.

Submetido em 11 de novembro de 2017 Aceito em 3 de maio de 2019 